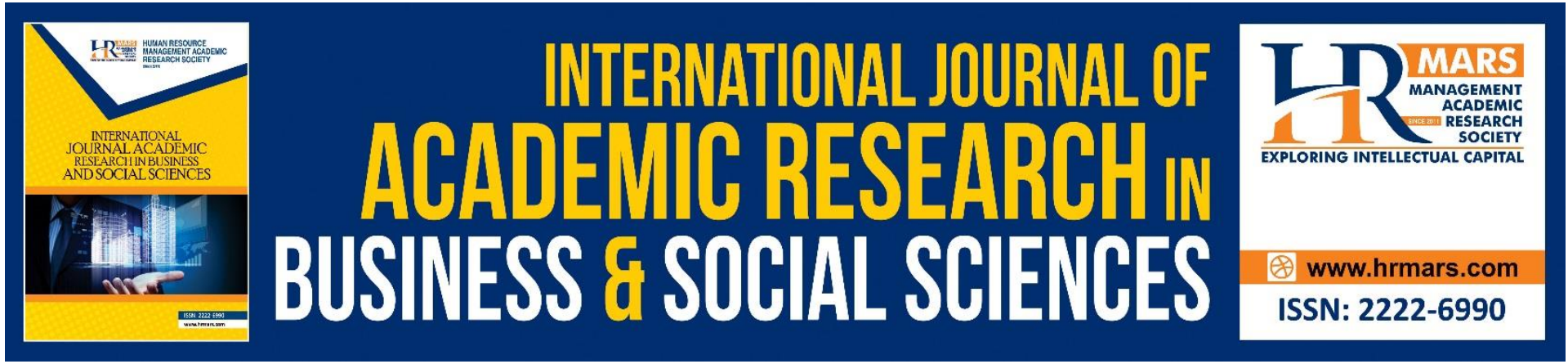

\title{
Five-Factor Model of Personality Traits Among Undergraduate Students Towards Intention to Join the Hospitality Industry in Greater Kuala Lumpur
}

\section{Mohd Zulfakar Mohd Nawi}

To Link this Article: http://dx.doi.org/10.6007/IJARBSS/v11-i9/10823 DOI:10.6007/IJARBSS/v11-i9/10823

Received: 23 July 2021, Revised: 25 August 2021, Accepted: 04 September 2021

Published Online: 17 September 2021

In-Text Citation: (Nawi, 2021)

To Cite this Article: Nawi, M. Z. M. (2021). Five-Factor Model of Personality Traits Among Undergraduate Students Towards Intention to Join the Hospitality Industry in Greater Kuala Lumpur. International Journal of Academic Research in Business and Social Sciences, 11(9), 613-625.

\section{Copyright: @ 2021 The Author(s)}

Published by Human Resource Management Academic Research Society (www.hrmars.com) This article is published under the Creative Commons Attribution (CC BY 4.0) license. Anyone may reproduce, distribute, translate and create derivative works of this article (for both commercial and non-commercial purposes), subject to full attribution to the original publication and authors. The full terms of this license may be seen at: http://creativecommons.org/licences/by/4.0/legalcode

Vol. 11, No. 9, 2021, Pg. 613 - 625

Full Terms \& Conditions of access and use can be found at http://hrmars.com/index.php/pages/detail/publication-ethics 


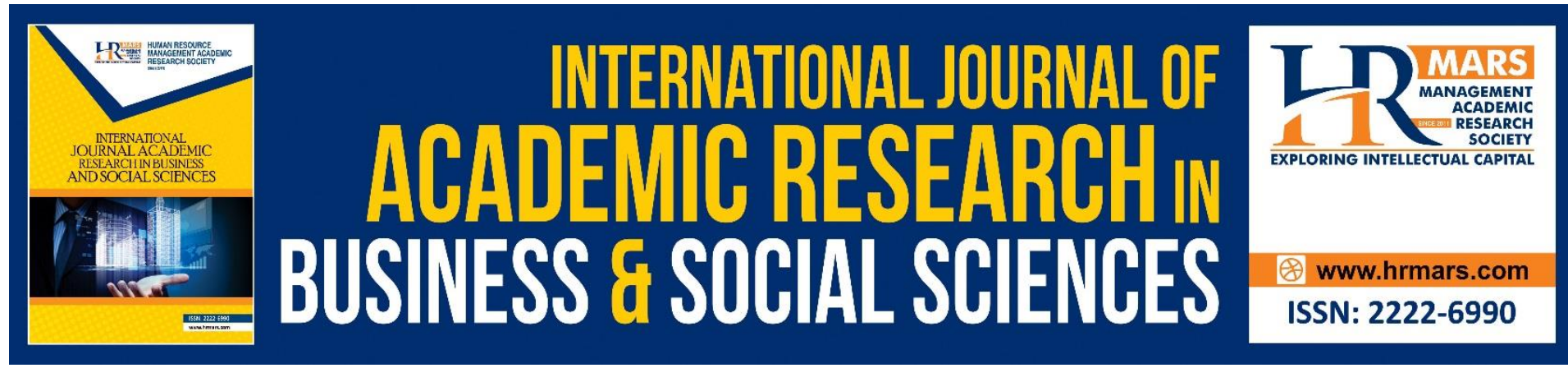

\title{
Five-Factor Model of Personality Traits Among Undergraduate Students Towards Intention to Join the Hospitality Industry in Greater Kuala Lumpur
}

\author{
Mohd Zulfakar Mohd Nawi \\ Department of Professional Education and Postgraduates, Faculty of Technical and \\ Vocational Education, Universiti Tun Hussein Onn Malaysia, 86400 Parit Raja, Batu Pahat, \\ Johor, Malaysia \\ Email: zuy.mzmn@gmail.com
}

\begin{abstract}
The purpose of this study is to determine the relationship between Personality Traits among undergraduate students towards intention to join the hospitality industry in Institutions of Higher Learning in the Greater Kuala Lumpur. This study employed Five-Factor Model of Personality Traits known as openness to experience, conscientiousness, extraversion, agreeableness, and neuroticism. A quantitative approach was employed. Questionnaires were distributed via online questionnaires. In total 397 responses were collected. Descriptive statistics and Correlation Analysis conducted for data analysis and Statistical Program for Social Science (SPSS) was used. This study found that Personality Traits were positively correlated with the intention to join the hospitality industry. Additionally, the result of this study indicated that openness to experience, conscientiousness, extraversion, agreeableness, and neuroticism as the Five-Factor Model of Personality Traits influences the intention of hospitality students to join the hospitality industry in the future. Practically, the outcomes of this study were beneficial to academia to understand the personality among hospitality undergraduate students. Theoretically, the findings of this study also provide academicians with the platform to achieve the valuable information on the current and real situation of hospitality students' intention to join the hospitality industry, thus eliminating gaps between literature and academic findings.
\end{abstract}

Keywords: Personality Traits, Five-Factor Model, Undergraduate, Students' Intention

\section{Introduction}

The hospitality and tourism industry play an essential role in Malaysia's economy due to the fact that tourist expenditure is increasing annually. Statistic from Tourism Malaysia (2019), shows that tourist arrivals had increased between 2010 and 2017, recorded the revenues for tourist expenses MYR 82.1 billion on 2017 (Tourism Malaysia, 2019). The information gathered from Tourism Malaysia website also recorded the arriving tourist to Malaysia increased by 5.5 per cent in 2016 with 26.76 million arrivals that worth MYR 82.1 billion 
(approximately USD 20.06 billion), 25.95 million in 2017 with MYR 82.1 billion (approximately USD 20.06 billion), and the latest statistics in 2019 shows that the tourist arrivals was at 26.10 million with MYR 86.1 billion (approximately USD 20.77 billion) (Hirschmann, 2020).

The hospitality and tourism industry in Malaysia have undergone vast growth and development since 2010 (Giap, Gopalan \& Ye, 2016). Moreover, Mosbah and Khuja (2014) mentioned that Malaysia has become one of the most important tourist destinations in the world. In addition, the hospitality and tourism industry are one of the important sources for foreign exchange revenues for several economies in Malaysia (Giap et al., 2016). Due to the increasing number of tourist arrivals, it will increase employment creation, especially in the hospitality businesses such as in lodging industry that represent a significant part of tourism industry apart from food and recreation industry (Poudel, 2013). This positive growth in the hospitality market will be an opportunity for the new talents to involve in the hospitality career. In addition, not everyone needs to have talents but they need to have skills to fit in this industry. According to Noe, Hollenbeck and Gerhart (2015), skills refer to an individual's level of performance in a given task or the ability to perform a job well and these skills can be divided into practical and communication skills.

A study by Berings, Poell and Simons (2005) stated, besides factors such as young workforce, low-skilled career, extra hour of work, and competition that affecting the intention of students to join the hospitality industry, individual characteristics and personality has also been identified as another factor that contributes to this issue. According to Hussain (2012), personality is the set of characteristics within an individual influencing his thoughts and behaviours in different contexts. Apart from that, Parks, Feldman and Bardi (2015) suggested that only Five-Factor Model (FFM) of Personality Traits (PT) as the appropriate essential of describing many fundamental aspects of the personality of an individual and these five are the basic dimensions to measure the individual's personality. Therefore, this study used the Five-Factor Model to determine the personality of hospitality students that associate them with the intention to join the hospitality industry.

\section{Problem Statement}

Abidin and Shariff (2015); Cavlek, (2008); Shariff, Kayat, \& Abidin (2014) found that the dynamic growth of tourism in Malaysia has positively and significantly contributed towards the growth of employment in the hospitality and tourism area. On the other hand, Shariff et al (2014) found that there are negative perceptions from hospitality graduates towards careers in the industry for instance low skilled job, need to work for extra hours and the negative perception towards certain hospitality industry, it adds to the industry's failure to employ the most skilled workforce. So, in order to cope with these mindsets, the acknowledgement of the importance of education in tourism and hospitality in producing quality graduates from the Ministry of Higher Education Malaysia (MOHE) (MOHE, 2016).

Between 2002 and 2005, the number of students registering in the hospitality and tourism programs is increasing rapidly. Unfortunately, the employment rates of the undergraduates' hospitality and tourism students were only thirty-nine per cent in a certain Asian country such as Taiwan (Teng, 2008). According to Pang (2010), the problem of low transition into the industry among hospitality and tourism students is indeed not new and is recognised as a nationwide problem. According to Robinson, Ruhanen, and Breakey (2016), students are 
becoming slightly less optimistic about jobs in the hotel industry and less likely to pursue a career in this particular industry. Zahari, Hanafiah, Othman, Jamaluddin, and Zulkifly (2010) also found that students became slightly less dedicated to a hospitality career, less eager to join and work and much less confident to take any job in order to stay in the hospitality and tourism industry. According to Tan, Baharun, Wazir, Anderson, Ali, Ghazali and Tarmazi (2015), most of the hospitality and tourism students are not keen to work in the hospitality industry after finishing their study.

In the present day, it is an essential duty of the educators, teachers, counsellors, and instructors to form a generation which possesses healthy and enriched Personality Traits, a higher level on the intelligence, a higher level of emotional intelligence, good coping abilities, and higher achievement orientation (Alghamdi, Aslam \& Khan, 2017). According to Kappagoda (2013), understanding someone's personality is very important to administrator because it is very helpful for assigning people into jobs and it gives them hints about how employees are likely to behave in different situations. Besides, the personality of the person has directly correlated with many works after-effect and attitudes (Judge, Heller \& Mount, 2002; Kappagoda, 2012; \& Organ, Podsakoff \& MacKenzie, 2006).

This study intends to determine the FFM of Personality Traits among hospitality undergraduate students in Higher Learning Institutions and their intention to join the hospitality industry. Students in hospitality and tourism programs from the Higher Learning of Institutions in the Greater Kuala Lumpur (Kuala Lumpur and Selangor area) are justified to be selected as the sample for this study because of they have undergone the internship during their undergraduate study. The location chosen is in the Greater Kuala Lumpur because most of the hospitality program are offered basically in Kuala Lumpur and Selangor.

\section{Research Question}

1. Which of the elements contribute the most of the Personality Traits among undergraduate students in hospitality program?

2. Which FFM of Personality Traits have the highest contribution towards the intention to join the hospitality industry?

\section{Literature Review \\ Hospitality Industry}

The hospitality and tourism industry are an important driver of the global economy creating hundred and nine million jobs and contributing USD 2.3 trillion (approximately MYR 9.5 trillion) (World Travel and Tourism Council, 2017). This associates with 10.2 per cent of the world's Gross Domestic Product (GDP) and sees one in ten jobs being hospitality and tourismrelated (World Travel and Tourism Council, 2017). Hospitality and tourism industry are important because this sector is one of the prime contributors to the economic growth of most countries which include Malaysia (Balasubramanian \& Ragavan, 2019). Malaysia as a tourist destination has achieved quite a few milestones locally as well as internationally and has been recognised as being in the top ten tourist destinations in the world and the world's fifth-best shopping destination by Expedia UK 2016 (Malaysian Investment Development Authority, 2019). According to the article in Malaysian Investment Development Authority (2019), Malaysia has been awarded the Medical Travel Destination of the Year, three years consecutively from 2015 by the International Medical Travel Journal's Medical Travel Awards. 
The government is strong-minded to push the hospitality and tourism sector to greater heights which is in line with the Malaysia Tourism Transformation Plan. According to the plan, by the year 2020, Malaysia has to attract thirty-six million tourists and generate MYR 168 billion in revenue from the hospitality and tourism industry (Malaysian Investment Development Authority, 2019).

\section{Hospitality Education in Malaysia}

In the case of Malaysia, the hospitality education is developed tremendously to fill in the gaps between hospitality education and the industry needs which is align with the expanding of the hospitality and tourism industry (Yusof, 2010). Malaysian hospitality and tourism industry have experienced remarkable growth and received strong support from the government. Yusof (2010) mentioned, in order to cater to the increasing employment potentialities and the request for the nicely able workforce, the range of hospitality and tourism education applications presented with the aid of higher getting to know institutions in Malaysia has elevated swiftly. Throughout the last thirty years, Goldsmith and Zahari (1994), training and education for hospitality are carried out by public and private higher learning institutions. Apart from universities, other colleges, polytechnics and community colleges are among the institutions participated in offering hospitality and tourism programs. According to Goldsmith and Zahari (1994), hospitality education in Malaysia has undertaken so numerous of adjustments since the first introduction by National Productivity Corporation (NPC) in the early seventies.

Hospitality programs play a crucial part in providing experienced and capable workforce. Society is becoming increasingly service-oriented since the changes in the globalization. The hospitality and tourism education in Malaysia are developing at a fast rate with so many public and private higher learning institutions are offering such a program. Because of that, hospitality and tourism management educators continually attempt to improve the quality of their programs (Assante, Huffman, \& Harp, 2009; Chang \& Yick Tse, 2015; Cho, Schmelzer, \& McMahon, 2002). Basaran (2016) mentioned that the importance of hospitality and tourism education has been recognized for many years. The issues of hospitality and tourism education have attracted various interests from the tourism scholars currently, especially in analysing the effectiveness of the curriculum. In Malaysia, empirical research on hospitality and tourism education is relatively new yet there are certainly many issues that need to be examined such as curriculum development, curriculum contents and the quality of programs (Yusof, 2010). In fact, the numbers of hospitality and tourism education programs have grown significantly over the last thirty years.

\section{Five-Factor Model of Personality Traits}

Personality is the set of characteristics within an individual influencing their perceptions and performances in different contexts (Hussain, 2012). Other study on the Five-Factor Model is mostly accepted for the personality traits constructs which contain the core dimension of personality (Costa \& McCrae, 1992). Costa and McCrae (1992) also stated that the Five-Factor Model include openness to experience, conscientiousness, extraversion, agreeableness and neuroticism was mostly used in the research. Table 1 explain the Five-Factor Model of Personality Traits and how they influence individual's attitudes toward choosing specific jobs or careers in the hospitality and tourism industry (Costa \& McCrae, 1992). 
Table 1: Five-Factor Model of Personality

\begin{tabular}{|l|l|}
\hline \multicolumn{1}{|c|}{ Construct } & \multicolumn{1}{c|}{ Description } \\
\hline Expenness to & $\begin{array}{l}\text { extent to which individuals exhibit intellectual curiosity, self- } \\
\text { awareness, and individualism/nonconformance (Costa \& McCrae, } \\
\text { 1992). }\end{array}$ \\
\hline Conscientiousness & $\begin{array}{l}\text { extent to which individuals value planning, possess the quality of } \\
\text { persistence, and are achievement-oriented (Costa \& McCrae, 1992). }\end{array}$ \\
\hline Extraversion & $\begin{array}{l}\text { extent to which individuals engage with the external world and } \\
\text { experience enthusiasm and other positive emotions (Costa \& } \\
\text { McCrae, 1992). }\end{array}$ \\
\hline Agreeableness & $\begin{array}{l}\text { extent to which individuals value cooperation and social harmony, } \\
\text { honesty, decency, and trustworthiness. Agreeable individuals also } \\
\text { tend to have an optimistic view of human nature (Costa \& McCrae, } \\
\text { 1992). }\end{array}$ \\
\hline Neuroticism & $\begin{array}{l}\text { extent to which individuals experience negative feelings and their } \\
\text { tendency to emotionally overreact (Costa \& McCrae, 1992). }\end{array}$ \\
\hline
\end{tabular}

\section{Intention to Join the Hospitality Industry}

The intention to join the hospitality industry analyse what students aim to do after their studies and what they want to do both short-term or long-term in their career path by taking demographic factors such as age, gender, academic achievement and their field of study. There are various studies on the intention to join the hospitality industry in identifying the attributes that influenced the career choice (Zahari, 2004). According to Zahari (2004), the popular attributes that found was significant relationship with the intention to join the hospitality industry among students such as long working hours, opportunity in career ladder, low salary and religious sensitivity like handling alcoholic beverages.

\section{Methodology}

Data are obtained by using self-administrated questionnaire generated from Google Form and distributed to respective respondents. The sample of this study is hospitality undergraduate students in the Greater Kuala Lumpur area consists of more than 20 private and public colleges, college universities and universities. The structured questionnaire was used as the research instrument of this study. Section A focused on the dimensions of the Five-Factor Model of Personality Traits while Section B focused on the students' intention to join the hospitality industry. According to Likert (1932), respondents were asked to provide their response using the Five-Point Likert scales, describing them accurately ranging from 1 (strongly disagree) to 5 (strongly agree). Demographic profiles were set in Section C using nominal scales and were focused on age, gender, race, the current level of program and hospitality industry experience. Browne (1995) mentioned that the use of 30 is commonplace at the time. Thus, a pilot test was conducted among 30 hospitality students from the diploma program in a private college and this sample excluded from the data analysis gathered. This study targeted to collect data a maximum of 384 samples based on Krejcie and Morgan (1970). For data collection procedure, 397 questionnaires were distributed and gathered through an online platform that can be shared through Facebook, Telegram, WhatsApp, email and other social media to private and public Higher Learning Institutions final semester hospitality students who had undergone internship and it can be shared from one to another. The method of analysis of this study incorporates the use of percentage table, frequencies 
distributions, and measures of central tendency. In contrast, the correlation between variables (independents and dependent variable) were analysed through multiple regression analyses.

\section{Results and Discussion Descriptive Analysis}

Based on the finding, female respondents are higher than the male. Out of 397 total respondents, $66.5 \%(n=264)$ are female respondents. With a ratio of $70: 30$, it is obvious that the male respondent group is smaller than the female with a considerable big margin $(n=133)$. It indicates that the previous study showed female sample are bigger than male. The result of respondents' age ranges between 17 to 19 years old (34.0\%), followed by age between 20 to 22 years old (39.5\%), age between 23 to 25 years old (16.4\%), age between 26 to 28 years old (7.6\%), age between 29 to 31 years old (1.5\%), and finally, age 32 years old and above $(1.0 \%)$.

Based on the result, the highest range of undergraduate students is from 20 to 22 years old. Most of the respondents are Malay students (58.7\%), followed by Chinese students (25.4\%), Indian students (9.3\%), and student from other races (6.5\%). The assumption that can be made is many of the undergraduate students who participated in this study are Malay. Finally, based on the current level of program, most of the respondents were from Diploma level with the total number of 225 respondents $(56.7 \%)$, followed by Degree level and the total number is 172 out of 397 respondents (43.3\%).

The descriptive statistics result from the Table 2 shows that conscientiousness contributes most of the Personality Traits among undergraduate students in hospitality program with a total mean score $(M)$ of $M=3.74(S D=0.892)$, followed by openness to experience with total mean score of $M=3.69(S D=0.941)$, extraversion with total mean score of $M=3.65(S D=$ 1.013), agreeableness with total mean score of $M=3.57(S D=0.992)$ and neuroticism contributes least effect of the Personality Traits among undergraduate students in hospitality program with total mean score of $M=3.56(S D=1.021)$. By looking at result gathered, the mean and standard deviation ranges from 3.35 to 4.04 and 0.825 to 1.073 accordingly for the intention to join the hospitality industry. Thus, the assumption can be made that most of the respondents are not sure either they want to join or not to join the hospitality industry after completing their study. 
Table 2: Descriptive Statistics of Five-factor of Personality Traits ( $N=397$ )

\begin{tabular}{|c|c|c|c|c|c|c|}
\hline No. & Construct & Indicator & Mean & $\begin{array}{l}\text { Total } \\
\text { Mean }\end{array}$ & $\begin{array}{l}\text { Std. } \\
\text { Dev. }\end{array}$ & $\begin{array}{l}\text { Total } \\
\text { Std. } \\
\text { Dev. }\end{array}$ \\
\hline \multirow{6}{*}{1.} & \multirow{6}{*}{$\begin{array}{l}\text { Openness to } \\
\text { experience }\end{array}$} & I am imaginative. & 3.88 & \multirow{6}{*}{3.69} & .822 & \multirow{6}{*}{.941} \\
\hline & & $\begin{array}{l}\text { I think about a lot of different } \\
\text { things at the time. }\end{array}$ & 3.77 & & .939 & \\
\hline & & I prefer routine tasks. & 3.43 & & 1.007 & \\
\hline & & $\begin{array}{l}\text { I love to read challenging } \\
\text { materials. }\end{array}$ & 3.49 & & 1.002 & \\
\hline & & $\begin{array}{l}\text { I always try to understand } \\
\text { myself. }\end{array}$ & 4.04 & & .885 & \\
\hline & & I am creative. & 3.54 & & .991 & \\
\hline \multirow{6}{*}{2.} & \multirow{6}{*}{ Conscientiousness } & I can complete task successfully & 3.92 & \multirow{6}{*}{3.74} & .756 & \multirow{6}{*}{.892} \\
\hline & & $\begin{array}{l}\text { I do not like to make last- } \\
\text { minute plans. }\end{array}$ & 3.50 & & 1.216 & \\
\hline & & I excel in what I do. & 3.59 & & .825 & \\
\hline & & I always make quick decisions. & 3.28 & & .924 & \\
\hline & & I always work hard. & 4.00 & & .859 & \\
\hline & & $\begin{array}{l}\text { I take responsibility for my } \\
\text { actions. }\end{array}$ & 4.15 & & .774 & \\
\hline \multirow{6}{*}{3.} & \multirow{6}{*}{ Extraversion } & I love to socialize with others. & 3.87 & \multirow{6}{*}{3.65} & .982 & \multirow{6}{*}{1.013} \\
\hline & & I prefer to be alone. & 3.07 & & 1.242 & \\
\hline & & I believe that I can be a leader. & 3.59 & & 1.066 & \\
\hline & & I enjoy being part of a group. & 3.93 & & .925 & \\
\hline & & I love to give my opinions. & 3.80 & & .981 & \\
\hline & & $\begin{array}{l}\text { I let things proceed at their } \\
\text { own pace. }\end{array}$ & 3.62 & & .882 & \\
\hline \multirow{6}{*}{4.} & \multirow{6}{*}{ Agreeableness } & I easily trust others. & 3.10 & \multirow{6}{*}{3.57} & 1.016 & \multirow{6}{*}{.922} \\
\hline & & I am easily satisfied. & 3.17 & & .977 & \\
\hline & & $\begin{array}{l}\text { I am easily concerned about } \\
\text { others. }\end{array}$ & 3.92 & & .864 & \\
\hline & & $\begin{array}{l}\text { I never suspect hidden motives } \\
\text { in others. }\end{array}$ & 3.20 & & .938 & \\
\hline & & $\begin{array}{l}\text { I value cooperation over } \\
\text { competition. }\end{array}$ & 4.11 & & .814 & \\
\hline & & I easily trust others. & 3.94 & & .925 & \\
\hline \multirow{6}{*}{5.} & \multirow{6}{*}{ Neuroticism } & I often feel stressed. & 3.27 & \multirow{6}{*}{3.56} & 1.018 & \multirow{6}{*}{1.021} \\
\hline & & I become stressed out easily. & 3.14 & & 1.123 & \\
\hline & & $\begin{array}{l}\text { I often become overwhelmed } \\
\text { by emotions. }\end{array}$ & 3.46 & & .991 & \\
\hline & & $\begin{array}{l}\text { I am afraid that I will do the } \\
\text { wrong things. }\end{array}$ & 3.83 & & 1.066 & \\
\hline & & I always try to keep cool. & 3.97 & & .918 & \\
\hline & & I often worry a lot. & 3.70 & & 1.010 & \\
\hline
\end{tabular}




\section{Correlation Analysis}

According to Pallant (2013), Pearson's correlation $(\rho)$ is used in order to explore the relationship between two variables and to find correlation where the direction is positive or negative. Based on the strength of correlation highlighted by Hair, Money, Samouel, and Page (2007) the Correlation Coefficient can be interpreted using indicators in Table 3.

Table 3: Pearson Correlation Coefficient Index

\begin{tabular}{|c|c|}
\hline R-Value & Strength of Correlation \\
\hline $0.00-0.10$ & Negligible correlation \\
\hline $0.10-0.39$ & Weak correlation \\
\hline $0.40-0.69$ & Moderate correlation \\
\hline $0.70-0.89$ & Strong correlation \\
\hline $0.90-1.00$ & Very Strong correlation \\
\hline \multicolumn{2}{|c|}{ Source: Hair et al. (2007) } \\
\hline
\end{tabular}

Table 4 shows that thirteen inter-correlations were statistically significant. Correlations among proposed variables were statistically significant ranging from $r=.369 * *(\rho<.01)$ to $r$ $=.675^{* *}(\rho<.01)$. The results in Table 3 presenting the variables proposed and FFM of Personality Traits were significant ranged from $r=.484^{* *}$ to $r=.675^{* *}$ while most of the correlations between variables proposed and intention to join the hospitality industry ranged from $r=.346^{* *}$ to $r=.425^{* *}$ except for intention to join the hospitality industry with neuroticism that does not significantly correlate at $r=.061$.

Table 4: Pearson Correlations ( $\rho$ ) Among Study Variables

\begin{tabular}{|c|c|c|c|c|c|c|}
\hline & OPENNESS & CONS & EXTRA & AGREE & NEURO & INTENTION \\
\hline OPENNESS & - & & & & & \\
\hline CONS & $.621^{* *}$ & - & & & & \\
\hline EXTRA & $.662^{* *}$ & $.675^{* *}$ & - & & & \\
\hline AGREE & $.529^{* *}$ & $.484^{* *}$ & $.500^{* *}$ & - & & \\
\hline NEURO & $-.384^{* *}$ & -.094 & $-.211^{* *}$ & $-.386^{* *}$ & - & \\
\hline INTENTION & $.369^{* *}$ & $.382^{* *}$ & $.346^{* *}$ & $.425^{* *}$ & .061 & - \\
\hline
\end{tabular}

**. Correlation is significant at the 0.01 level (2-tailed).

\section{Discussion and Conclusion}

The main objective of this study was to determine which FFM of Personality Traits that associates with undergraduate students in the hospitality program at private and public Higher Learning Institutions focusing on the Greater Kuala Lumpur area towards their intention to join the hospitality industry. In line with the previous research conducted by Atta, Ather and Bano (2013), it has been proposed that each individual fall between the two edges of each dimension. Basically, there were five dimensions of the Five-Factor Model of Personality Traits measured. It consists of openness to experience, conscientiousness, extraversion, agreeableness, and neuroticism. Neuroticism differs elements of emotional stability with those of negative emotionality. Next, extraversion implies a dynamic approach to the world as opposed to a passive approach and they are often full of energy and actively seek out attention from others, while openness examines an individual's openness to 
experiences against their level of close-mindedness. It also indicates individuals in this dimension are more creative and able to express and understand their emotions. Third, agreeableness seeks out to measure whether one has a prosocial orientation towards others or if they act with antagonism. They are, indeed, altruistic, warm, generous, trusting and cooperative. In a very straight way, an agreeable person is concerned with the welfare and interest of other people. Finally, according to Hergenhahn and Olson (1999), conscientiousness includes the control of desires which facilitates tasks and other goaldirected behaviour and They are very responsible with work and very careful to make decisions.

Working in the hospitality and tourism industry can be instantaneously rewarding and difficult, and individuals who can understand how and why they react to these situations, as they resist the positive or negative emotions inherent in the service delivery process (Walsh, Chang \& Tse, 2015). This is important because the two traits resulted in chapter four might encourage students to join the hospitality industry despite some negative external factors, such as sufficient in monetary but not extraordinary pay, promotion opportunities to build up their careers, and extra working hours. The result of this study indicated that openness to experience, conscientiousness, extraversion, agreeableness and neuroticism as the FFM of Personality Traits influences the intention of hospitality students to join the hospitality industry in the future. Understanding students' personality to embark in the industry is crucial to both educators and practitioners.

The findings from this study will contribute to the knowledge base for Malaysian hospitality and tourism programs, especially for higher learning institutions in the public and private sectors. The results will apply directly to hospitality students to the literature on the personality traits of students. So, it will increase the level of understanding of the nature of hospitality students and their intentions to join the hospitality industry. From the practitioner point of view, the result of this study can be used to broaden study the factors that influence the intention of the students to join the hospitality and tourism industry from the hospitality and tourism programs. The research may provide a better understanding of the industry's challenges in recruiting quality graduates. Studies into the purpose of hospitality students to enter the industry will provide the higher learning institutions with a better opportunity or concept to inspire or encourage students to graduate from the hospitality industry.

\section{Limitation and Recommendation for Future Study}

There is no doubt that there are some limitations to this study. Although the results can be adapted by the hospitality industry, this study focused only on hospitality students in Higher Learning Institution in both private and public Higher Learning Institution only in the Greater Kuala Lumpur and the recommendation is this research should be expanded in all universities and colleges that offer hospitality and tourism programs in West Malaysia, Sabah and Sarawak.

In addition, Personality Trait research among hospitality undergraduate students in Malaysia is still at the anatomy stage. Thus, regional literature in this field is therefore inadequate 
compared to other countries. Consequently, with no considerable selection, this research has relied more on papers and publications from abroad. Some issues can lead to the study's vulnerabilities. The data was obtained, for instance, solely through a self-reported process, without multiple sources being included. Like most other research, the most common and prevalent issue is the issue of sample size because it is somewhat difficult to generalize the findings as sample only in the Greater Kuala Lumpur and students whose undergone practical training and to find those students are hard and unable to detect which of the correspondent has some experiences with hospitality industry.

\section{References}

Abidin, A. Z., \& Shariff, N. M. (2015). Developing an Index of The Malaysian Tourism and Hospitality Graduates Competencies. International Journal of Business and Society, 16(3), 422-435.

Alghamdi, N. G., Aslam, M., \& Khan, K. (2017). Personality Traits as Predictor of Emotional Intelligence among the University Teachers as Advisors. Education Research International, 2017, 1-6. DOI:10.1155/2017/9282565

Assante, L. M., Huffman, L., \& Harp, S. S. (2009). A taxonomy of academic quality indicators for U.S.-based 4-year undergraduate hospitality management programs. Journal of Hospitality \& Tourism Research, 34, 164-184.

Atta, M., Ather, M., \& Bano, M. (2013). Emotional Intelligence and Personality Traits among University Teachers: Relationship and Gender Differences.

Balasubramanian, K., \& Ragavan, N. (2019), "What are the key challenges faced by the Malaysian hospitality and tourism industry in the context of industrial revolution 4.0?", Worldwide Hospitality and Tourism Themes, Vol. 11 No. 2, pp. 194-203.

Basaran, K. (2016). Experiential Learning in Tourism Education in North Cyprus. Academic Dissertation, University of Tampere, Finland.

Berings, M. G. M. C., Poell, R. F., \& Simons, P. R. J. (2005). Conceptualizing on-the-job learning styles. Human Resource Development Review, 4, 373-400.

Browne, R. H. (1995). 'On the use of a pilot study for sample size determination'. Statistics in Medicine. Vol 14. Pages 1933-1940

Cavlek, N. (2008). Tourism Education Through Experienced Learning: A Case of ITHAS. Conference Proceedings: An Enterprise Odyssey: Tourism Governance and Entrepreneurship.

Chang, S., \& Yick-Tse, E. C. (2015). Understanding the Initial Career Decisions of Hospitality Graduates in Hong Kong: Quantitative and Qualitative Evidence. Journal of Hospitality \& Tourism Research, Vol. 39, No.1, February 2015, 57-74, DOI: $10.1177 / 1096348012461544$

Cho, W., Schmelzer, C., \& McMahon, P. (2002). Preparing hospitality managers for the 21st century: The merging of just-in-time education, critical thinking, and collaborative learning. Journal of Hospitality \& Tourism Research, 26, 23-37

Costa and McCrae. (1992). The NEO-PI Personality Inventory, Odessa, FL, USA: Psychological Assessment Resources.

DOI: 10.5829/idosi.wasj.2014.31.11.718.

Giap, T., Gopalan, S., \& Ye, Y. (2016). Drivers of Growth in the Travel and Tourism Industry in Malaysia: A Geweke Causality Analysis. Economies, 4(1), 3.

DOI:10.3390/economies4010003 
Goldsmith, A., \& Zahari, S. (1994). Hospitality Education in Malaysia: Filling the Skill Gap. International Journal of Contemporary Hospitality Management, Volume 6 (6), 27-31.

Hair, J. F., Money, A. H., Samouel, P., \& Page, M. (2007), "Research Methods for Business", Education + Training, Vol. 49 No. 4, pp. 336-337.

https://doi.org/10.1108/et.2007.49.4.336.2

Hergenhahn, B. R., \& Olson, M. H. (1999). An introduction to theories of personality (5th ed.). Prentice-Hall, Inc.

Hirschmann, R. (2020). Tourist arrivals to Malaysia 2010-2019. Statista. https://www.statista.com/statistics/1004711/tourist-arrivals-malaysia/

Hussain, S. (2012). Personality and career choices. African Journal of Business Management. 6. 10.5897/AJBM11.2064.

Judge, T. A., Heller, D., \& Mount, M. K. (2002). Five-Factor Model of personality and job satisfaction: A meta-analysis., Journal of Applied Psychology, 87, 530-541.

Kappagoda, D. (2013). The relationship between emotional intelligence and the five-factor model of the personality of English teachers in Sri Lanka.

Kappagoda, S. (2012). The Impact of Work-Related Attitudes on Task and Contextual Performance: A Comparative Study in Public and Private Banks in Sri Lanka.

Malaysian Investment Development Authority (MIDA), (2019). Retrieved from https://www.mida.gov.my/home/hospitality/posts

MOHE. (2016). Ministry of Higher Education, Malaysia.

Mosbah, A., Khuja, M. S. A. A. (2014). A Review of Tourism Development in Malaysia. European Journal of Business and Management, Vol. 6, No. 5 (2014) ISSN 2222-1905.

Noe, R. A., Hollenbeck, J. R., \& Gerhart, B. (2015). Fundamental of Human Resource Management. New York: McGraw-Hill.

Organ, D. W., Podsakoff, P. M., \& MacKensie, S. B. (2006). Organizational Citizenship Behaviour. Its Nature, Antecedents, and Consequences. Sage Publication: Thousand Oaks.

Pallant, J. (2013). SPSS Survival Manual: A Step-by-Step Guide to Data Analysis Using SPSS (3nd Ed.). Journal of Advanced Nursing.

Pang, J. M. (2010). Perceptions of the Tourism and Hospitality Industry by Singapore Polytechnic Hospitality Students: An Exploratory Study Master Degree, University of Nevada, Las Vegas, Singapore.

Parks-Leduc, L., Feldman, G., \& Bardi, A. (2015). Personality and Values: A Meta-analysis. Personality and Social Psychology Review, 19: 3-29. Parks-Leduc, L.

Poudel, S. (2013). The Influence of The Accommodation Sector on Tourism Development and Its Sustainability: Case Study: Strand Camping, Larsmo.

Robinson, R. N., Ruhanen, L., \& Breakey, N. M. (2016). Tourism and hospitality internships: influences on student career aspirations. Current Issues in Tourism, 19(6), 513-527.

Shariff, N. M., Kayat, K., \& Abidin, A. Z. (2014). Tourism and Hospitality Graduates Competencies: Industry Perceptions and Expectations in the Malaysian Perspectives. World Applied Sciences Journal, 31(11), 9.

Tan, Z. M. A., Baharun, N., Wazir, N. M., Anderson, N., Ali, N. M., Ghazali, N., \& Tarmazi, S. A. A. (2015). Graduates' Perception of the Factors Affecting Commitment to Pursue Career in the Hospitality Industry. Procedia-Social and Behavioural Sciences.224 (2016), 416- 420. 
Teng, C. (2008). The Effects of Personality Traits and Attitudes on Student Uptake in Hospitality Employment. International Journal of Hospitality Management, 27, 86.

Teo, H., Bernhard, S., \& Hok, Y., C. (2017). In Focus: Malaysia A Rising Opportunity. Retrieved from https://www.hvs.com/Print/In-Focus-Malaysia-A-Rising-Opportunity=8008.

Tourism Malaysia. (2019). Ministry of Tourism and Culture Malaysia Retrieved from https://corporate.tourism.gov.my/statistics.

Walsh, K., Chang, S., \& Yick Tse, C. (2015). Understanding Students' Intentions to Join the Hospitality Industry: The Role of Emotional Intelligence, Service Orientation, and Industry Satisfaction. [Article]. Cornell Hospitality Quarterly, Volume 56 (4), 16. DOI: 10.1177/193896551455247.

World Travel \& Tourism Council. (2017). Travel \& Tourism Economic Impact 2014 Malaysia. Retrieved from http://www.wttc.org//media/files/reports/economic\%20impact\%20research/country \%20reports/malaysia2014.pdf.

Yusof, M. F. M. (2010). The Issues of Hospitality and Tourism Education in Malaysia.

Zahari M. S. M., Hanafiah M. H., Othman Z., Jamaluddin M. R., Zulkifly M. I. (2010). The declining interest of hospitality students toward careers in the hotel industry: Who's to be blamed? Interdisciplinary Journal of Contemporary Research in Business 2:269-87.

Zahari, M. (2004). Factors Influencing Students of Choosing Hospitality Programme and Commitment Toward Careers in The Industry. 10.13140/RG.2.1.3511.0647. 